\section{THE RECORD OF PICTURESQUE BRITAIN}

\section{By DR. VAUGHAN CORNISH}

$\mathrm{T}$ $\mathrm{HE}$ second year's work of artists engaged in recording picturesque features of England and Wales is now on view at the National Gallery, London. This valuable work, initiated by a committee set up by the Ministry of Labour and National Service, has been made possible by a grant from the Pilgrim's Trust. It is intended that the drawings (which are the property of the Trustees) shall ultimately form a permanent collection.

A special feature of the present exhibition is a group of drawings of Windsor Castle by John Piper, lent by H.M. The Queen, who commissioned their execution after last year's exhibition. The rest of the present collection of drawings (about two hundred in number) includes examples from twenty counties, of which ten counties are additional to those comprised in last year's exhibition.

Of picturesque Buckinghamshire a charming corner house in Winslow and the red-brick town hall of Buckingham are faithfully depicted by Stanley Anderson, R.A. Notable examples of London and its environs are the Embankment, Pimlico, by Edward Walker, and The Admiral's House, Hampstead, by Norman James. Petersham and Ham in Surrey have been recorded in detail, both on account of the beauty of their seventeenth-century houses and the special risk of demolition owing to the nearness of London. Among these pictures are a general view of Ham Common, and the representation of two houses at Petersham with Dutch gable-ends facing the road.

Of towns in Hertfordshire, the steep street of Bishop's Stortford is shown in a charming pen-andink sketch by S. R. Badmin. The broad, open spaces of flat Suffolk are well shown in Martin Hardie's water-colour of Bawdsey Ferry.

On the western side of England, Ledbury in Herefordshire has been selected for its remarkable timberframe houses ; and, finally, crossing to Wales, Mona Moore's water-colour shows the low stone houses, of the fifteenth and sixteenth centuries, offset by a moun tainous background.

In addition to buildings, the record of articles in use comes within the scope of the record of picturesque Britain. An interesting example is shown in Kenneth Rowntree's careful drawing of a coracle, the primitive boat which has come down from British times.

As this present World War goes on, we need to consider more carefully than hitherto the importance of the beauty of town and countryside in relation to the nation's welfare. When we look back to the early eighteenth century, we find the beauty of the countryside enhanced in both building and planting by the educated taste of the great landowners. Without attempting to consider the justification or otherwise of the taxation to which they are now subject, there is no doubt that if their mansions and parks be not preserved, the nation will lose one of its greatest assets of beauty. At the present time, it is of great importance to realize that an environment of beauty is no mere luxury but an essential condition for the happiness and spiritual welfare of the nation. If, however, such an environment is to confer its full benefit, the nation as a whole must be educated in the appreciation of scenery, both natural and architectural. Now that, in the twentieth century, educa- tion is no longer confined to the well-to-do classes, the proper understanding and full enjoyment of the æsthetics of scenery can be brought within the reach of all, if, but only if, the subject is brought properly before the attention of the whole community. Picture galleries are, of course, a help, but by no means sufficient. The most evident means at the command of the Government is a weekly broadcast allotted to the systematic teaching of the rsthetics of scenery.

\section{COMMUNICATION PROGRESS}

TN a lengthy article entitled "Milestones of Communication Progress" (Elect. Comm., 20, No. 3 ; 1942), H. T. Kohlhaas presents a comprehensive review of the developments in electrical communication which have occurred within the last twenty years. In the planning and co-ordinating of longdistance telephone communication, an outstanding event was the creation in 1924 of the International Consultative Committee on long-distance telephony in Europe, following a proposal made by Sir Frank Gill in his presidential address to the Institution of Electrical Engineers in 1922. Between 1923 and 1926 a succession of recorded steps led to the establishment of the first trans-Atlantic radiotelephony circuit between the United States and England. The first Madrid-Buenos Aires radiotelephone circuit was inaugurated in 1929 and it was followed in 1930 by the first radiotelephone circuit between the Americas. In 1931 the first demonstrations of single sideband short-wave radiotelephony were carried out between Buenos Aires and Madrid and between Madrid and Paris, establishing the now well-recognized improvements in transmission efficiency and the economies which this method makes possible.

In 1931 and the following years outstanding developments in the ultra-high frequencies were described. Long-distance telephone communication was established across the English Channel on approximately $1,600 \mathrm{mc}$. using very sharp beams. Work in this general field was continued with great activity and publications appeared on propagation of these very high frequencies in 1936 and 1937, the latter including a description of the first multichannel ultra-short wave telephone link. Later, work on ultra-high frequencies was directed also to television transmission. On one hand, there were references in 1939 to the Eiffel Tower television station delivering $30 \mathrm{kw}$. to an exceptionally long feeder over the wide band of frequencies necessary for television, and on the other, to transmission over dielectric guides at frequencies from $1,000 \mathrm{mc}$. to 30,000 mc., using various types of positive grid triodes, klystrons, magnetrons or other tube structures.

High-power broadcasting on intermediate frequencies and high frequencies took a prominent place at this period. The Prague station with $120 \mathrm{kw}$. carrier was described in 1932 and was followed two years later by the Budapest station with the same carrier power. The latter was unique for its antifading mast antenna over 1,000 feet high, the highest antenna ever constructed. On higher frequencies, mention was made of two British Empire transmitters added in 1937 at Daventry, rated at $50 \mathrm{kw}$. carrier power at 22 mc. Early long-distance telephone communication to ships at sea was also recorded: on the Berengaria in 1929; the Belgen- 
land in the winter of 1930-31 and the Empress of Britain in 1931-32. Successful conversations were held with London when a ship was in the China Sea and with New York when at Alexandria. Service to the Majestic was opened on February 14, 1930, at first for incoming calls only.

Important work on automatic direction finders was done in 1934 and onwards and an aeroplane automatic radio compass was described in 1936. This equipment was introduced in the United States in 1937, and important experiments were made and papers published on night error and mountain effects. The subject of ground direction finders avoiding polarization errors by the use of spaced vertical antennæ with high-frequency transmission line to distant receivers was studied around 1938 as was that of aerial navigation.

Less spectacular, but fundamental, were developments in automatic telephony and transmission in which field the application of machine switching to large areas, the rapid expansion of rural automatic networks and, in recent years, schemes involving complete national dialing in some of the smaller European countries, either on a timed and zoned metering basis or on an automatic ticketing basis, were outstanding examples. These national dialing schemes led to the development of a commercially practicable system for automatic toll ticketing, each ticket containing a complete record of each subscriber's telephone call. In 1937, 1939 and 1940 a series of articles appeared showing how automatic toll ticketing was developed and introduced com. mercially.

The wire transmission systems went through an evolution just as remarkable as that of automatic switching. References to the first carrier telephone systems in Brazil and Australia appeared in 1924 and 1925 respectively ; the first loaded and repeatered long-distance French telephone cable, in 1927; and the first twelve-channel carrier systems and the first coaxial cable in England in 1937. Several lines of development, continued year after year, are only now yielding their reward in connexion with war efforts, and this is especially true of much of the work done on aerial navigation, on direction finding and in the general field of ultra-high frequencies. This 43-page review contains much of historical interest, and concludes with a list of 159 references to papers, etc., published during the period surveyed.

\section{FORTHCOMING EVENTS}

\section{(Meeting marked with an asterisk is open to the public)}

Tuesday, July 14

INSTITUTE OF PETROLEUM (JOINT MEETING WITH THE INSTITUTION OF CHEMTOAL ENGINEERS AND THE CHEMTCAL ENGINGRRING GROUP OF THE SOCIETY OF CHEMICAL INDUSTRY) (at the Institution of Mechanical Fngineers, Storey's Gate, London, S.W.1), at 5.30 p.m.Dr. M. Ruhemann : "The Separation of Gases".

Wednesday, July 15

INSTTTUTE of ChEMISTRX (LONDON AND SOUTH BAsTBRN CoUNTIES ShCTION) (at 38 Russell Square, London, W.C.1), at 6 p.m.-Dr. J. Grant: "Chemist versus Forger".

\section{Thursday, July 16}

London Schoor of Hygiene aNd TropicaI Mrdicing (at Keppel Street, London, W.C.1), at 2.30 p.m.-Prof. Major Greenwood, F.R.S. : "Civilian Hazard of Life in this War and in the Last-a Proflt and Loss Account for 1915-16 and 1940-41".*

\section{Friday, July 17}

Physical Society (Optical Grodp) (in the Physics Department of the Imperial College, Imperial Institute Road, London, S.W.7), at 5 p.m.-Mr. F. Twyman, F.R.S. : "The Interferometer in Lens and Prism Manufacture".

\section{APPOINTMENTS VACANT}

Apputcations are invited for the following appointments on or before the dates mentioned :

Hradmaster of the Portsuouth Gramutr Sohool-The Chairman of the Governors, Paymaster Rear-Admiral G. Grant, 4 old Cottages, Church Hill, Midhurst, Sussex (July 18).

Thaoher of Physics, Mathematios and engrnegring Solence and a TEAOHER OF WORESHOP PRAOTIOE, in the Doncaster Technical College-The Chief Education Officer, Education Offices, Doncaster (July 21).

VETERTNART INVESTTGation OFFICER-The Secretary, West of Scotland Agricultural College, 6 Blythswood Square, Glasgow (July 30 ). Two Demonstrators (MALt on Femalt) in ANatomy-The Registrar, The University, Sheffield (July 31).

LECTURER IN THE DEPARTMENT OF CHEMISTRY-The Registrar, University College, Southampton (August 4).

Teacher for Day and Evening Engineering Crassre, and a TEACHER FOR ENGINEERING WORKSHOP PRACTICR A YD METALWOREThe Principal, County Technical College, Gainsborough.

\section{REPORTS and other PUBLICATIONS} (not included in the monthly Bools Supplement)

Great Britain and Ireland

Memoirs of the Cotton Research Station, Trinidad. Series A: Genetics, No. 18 : Anthocyanin Pattern in Asiatic Cottons. By R. A Silow and O. P. Yu. Pp. 219-284. (London: Empire Cotton Growing
Corporation.) 2s. 6d. Royal Meteorological Society. Bibliography of Meteorological Literature. Prepared by the Royal Meteorological Society with the collaboration of the Meteorological Office. Vol. 5, No. 2, July-December 1941. Pp. 13-30. (London: Royal Meteorological Society.) Hertfordshire County Council. The School Child and the school Canteen. An Inquiry undertaken by F. LeGros Clark and presented to the Education Committee. Pp. 36. (Hertford : County Hall.) [256 Annual Reports on the Progress of Chemistry for 1941. Vol. 38 Annual Reports on the Progress of Chemistry for 1941. Vol. 38.
Pp. xxxii +326. (I ondon: Chemical Society.) 15\%. Geological Survey of Great Britain : Scotland. Wartime Pamphlet No. 27: The Oil-Shales of the Lothians-Structure. Area 1: West Calder. By Dr. J. E. Richey; with Appendix by $W$. Manson and Contributions by iw. E. Graham. Pp. 42. (London: Geological
Survey and Museum.) 18. 10d.

\section{Other Countries}

U.S. Office of Education : Federal Security Agency. Bulletin 1940, No. 6 (Monograph No. 5): Pupil Personnel Services as a Function of State Departments of Education. By David Segel and Maris M. Proffitt. (Studies of State Departments of Education.) Pp. vi +84. 15 cents. Bulletin 1941, No. 7: School Library Administration as Annotated Biblíography. Prepared hy Nora E. Beust. Pp. vi +82. University of Illinos : Fngineering Experiment Station. Bulletin Series No. 334: The Effect of Range of Stress on the Fatigue Strength of Metals. 38 James O. Smith. Pp. 49. 55 cents. Reprint Series No. 22: Eighth Progress Report of the Joint Investigation of Fissures n Railroad Rails conducted by the Engineering Experiment Station, University of Illinols, in co-operation with the Association of American Railroads and the Rail Manufacturers Technical Committee. By
Herbert F. Nooore. Pp. 38 . 15 cents. (Urbana, Ill.: University of Tllinois.) Proceedings of the United States National Museum. Vol. 92, No. 3139 : The Chrysomelid Beetles Luperodes bivattatus (LeConte) and Varicornis (LeConte) and some Allied Species. By Doris $\mathbf{H}$. Blake. Pp. 57-74+plates 5-6. Vol. 92, No. 3140 : Notes on the Classification of the Staphylinid Beetles of the Groups Lispini and Osoriinm. By Richard E. Blackwelder. Pp. 75-90. (Washington, D.C.: Govern-
ment Printing Offlce.) U.S. Department of Agriculture. Farmers' Bulletin No. 1886 The Beet Leafhopper. By W. C. Cook. Pp, ii +21 . (Washington; University of California Puhlications in Zoology. Vol. 46, No 1. The White-crowned Sparrows (Zonostrichin leucophrys) of the Pacifo Seabard: Fnvironmand chard. Pp iiit+178 (20 plates). (Berkeley and Barbara. Planchard. Pp. ili 178 (20 plates). (Berkeley an Press.) 2 dol]ars.
Prita Forest Bulletin No. 106 (Silviculture Series): The Control of Lantana by a Sodium Chlorate Spray. By A. L. Griffith. Pp. vi $+8+2$
plates. (Delhi : Manager of Publications.) 6 annas; $7 d$. Imperial Council of Agricultural Research. Miscellaneous Bulletin No. 37: Milk Records of Cattle in Approved Dairy Farms in India. Vol. 2 (Becords received during 1937-38), Part 2: Buffaloes. Compiled by the Animal Husbandry Bureau, Imperial Couneil of Agricultural Research. Pp. vi +325-614. (Delhi : Manager of Publications.)
5 rupees; 88 .

\section{Catalogues}

Electric Furnaces. (Publication 51.) Pp. 4. (London: Johnson, Matthey and Co., Ltd.)

Glo-Pass Security System. Pp. 12. (Juondon: Colloidal Research Laboratories, Ltd.)

Chance-Parsons Optical Glass. (CP.400.) Pp. 22. (Smethwick: Chance Brothers and Co., Ltd.) 